\title{
CITTASLOW SOM CITYBRAND - KAMPEN FOR AT GENVINDE DEN LOKALE HETEROGENITET
}

Lad os starte med at smage på et interessant begreb: Guggenheimification (Kiib og Andersen). Rent etymologisk refererer termen til det berømte Guggenheim Museum i den lille spanske fiskerby Bilbao, der med opførelsen af Frank O. Gehrys berømte kunstbygning er blevet en attraktiv turistmagnet. Undersøgelser viser, at $80 \%$ af Bilbaos turister udelukkende kommer til byen for at besøge Guggenheim Museet (Engstrøm). Det lyder lokkende let: At skabe et godt citybrand, der sætter byens urbane rum på landkortet. I hvert fald hvis man skuer til Bilbao. Sandheden er imidlertid, at Bilbaos succes er et enestående tilfælde. Sætter man sig for at undersøge det, man kunne kalde citybrandingens kulturbistorie, så tegner der sig nemlig et meget tydeligt billede af, at det har vist sig slet ikke at være så let og ligetil at konstruere succesfulde og attraktive citybrands, der bidrager nævneværdigt til at ændre byens eksisterende image. Begrebet guggenheimification skal derfor opfattes som en både lidt nedladende, men også ironisk begrebsliggørelse af tendensen til, at rigtig mange byer siden slutningen af 1990 `erne i jagten på skabelsen af det unikke citybrand, i virkeligheden ofte er endt med at gøre det samme: løbe efter de samme kulturelle strategier og udvikle sig efter en meget uniform oplevelsesorienteret tankegang. Et paradoksalt træk ved citybrandingens kulturhistorie er således, at mange byer i kampen om at blive "et hot spot" har efterstræbt en unikhed, som utilsigtet og på en og samme tid er blevet til en perlerække af ligheder den vestlige verdens byer imellem (Löfgren). Mange europæiske storbyer har igennem de sidste ti år fået et stadig mere standardiseret kulturelt udtryk i form af meget identiske oplevelsesrum med prominente havnemiljøer, attraktive cafémiljøer, store shopping malls og nye bydele med det perfekte mix af hightech og hightouch, som Orvar Löfgren formulerer det. Alt sammen så gennemkonstrueret og planlagt, at man kommer til at længes efter en plamage, noget uafstemt, som en skribent på Weekendavisen blandt andet har sagt om Ørestaden i København med tilføjelsen om, at denne nye bydel næsten ser ud til at have været udsat for fransk vask og strygning (Weiss).

Den sydfynske provinsby Svendborg er i denne sammenhæng yderst interessant, fordi den netop har forsøgt at gå mod den oplevelsesøkonomiske flodbølge med en hidtil ukendt og uafprøvet citybrandingstrategi på dansk jord. I snart to år 
har Svendborg Kommune været medlem af det internationale netværk af Cittaslowbyer, og med et logo, der prydes af en orange snegl med en by på ryggen, kan Svendborg i dag bryste sig af at være Danmarks første og på nuværende tidspunkt eneste "langsomme by". Et faktum der for de flestes vedkommende er gået ganske ubemærket hen - selv for indbyggerne i Svendborg Kommune (en problematik vi afslutningsvis skal vende tilbage til). Dette gør dog ikke Cittaslowbevægelsen mindre interessant, når man vil forsøge at begribe den i et bredere kulturanalytisk perspektiv. Med Cittaslowbevægelsen som kerneobjekt søger denne artikel at belyse, hvilken citybrandingstrategi der ligger bag markedsføringen af sig selv som værende en bevidst "langsom by".

På nuværende tidspunkt eksisterer der cirka I2o Cittaslowbyer på verdensplan, som er organiseret i et netværk, der rent organisatorisk har hovedkontor i Italien, hvorfra bevægelsen udspringer. For at blive medlem af Cittaslowbevægelsen skal man som by certificeres, i den forstand at man skal opfylde nogle særlige bykulturelle betingelser, som især knytter sig til byens historiske og sociale kvaliteter. Samtidig er et afgørende krav, at byen, der søger om optagelse, maks. må have et indbyggertal på 50.00o. Følgende citat hentet fra slowfilosofien giver et nærmere billede af, hvilken bykulturel strategi der er på spil i Cittaslowbyen:

"At leve i en Cittaslow, enten som borger eller som medlem af bystyret, er en livsform, hvor dagligdagen føres på nye præmisser i forhold til de gældende normer. Her er der fokus på et langsommere tempo, og menneskelighed og økologisk levevis vægtes højere end produktivitet og hurtighed. Det er en livsform, der er mere solidarisk med så vel nutidige som fremtidige generationer, og hvor der udvises respekt for de lokale særpræg og værdier i en stadig mere globaliseret verden.” (Manifest for Slowfilosofien)

\section{Fra Slow Food til Cittaslow}

Cittaslowbevægelsen er en udløber af Slow Food-bevægelsen, som blev grundlagt i I986 som en direkte reaktion mod planerne om at opføre en McDonald's-restaurant ved den Spanske Trappe i Rom (Møller 3). Slow Food-bevægelsens erklærede mål er at udbrede princippet om mad, "der er lavet fra bunden", men indeholder samtidig et ønske om at styrke den lokale kultur, idet Slow Food-bevægelsen samtidig profilerer sig på vigtigheden af at fremme brugen af lokale råvarer. Bevægelsen må derfor både forstås som et opgør med den fastfoodkultur, der for alvor fik fat i det vestlige samfund i løbet af I980'erne, og som et modsvar til den globale monokultur - amerikaniseringen af vores samfund - som McDonald's måske mere end noget andet er blevet en kulturel metafor for. I 1996 bredte filosofien omkring langsom mad sig til det bykulturelle plan, da den italienske borgmester Paulo Santurnini fra byen Greve tog initiativ til at oprette Cittaslowbevægelsen. Tegnet Cittaslow kan karakteriseres som et oxymoron, idet det er sam- 
mensat af to modsatrettede begreber "by" og "langsom" (Madsen). Et sprogligt paradoks der i mange henseender synes at forstyrre brandet. For mens det for Slow Food-bevægelsen giver god mening at brande sig på dikotomien til hurtig mad (fastfoodkulturen), så er rationalet knap så klart, når man som Cittaslow skal markedsføre sig på, hvorfor det er godt at være en langsom by frem for en hurtig i et senmoderne, højteknologisk, omskifteligt og globalt samfund. Ikke underligt, så misforstås Cittaslowbevægelsen netop ofte som et nostalgisk koncept, der anklages for ikke at indeholde meget andet end trangen til at ønske sig tilbage til en svunden tid med hestevogne, halm i træskoene og brostensbelagte gader. Bevægelsens markante fokus på bevarelsen og udviklingen af byens lokale særpræg og værdier betyder dog, at den først og fremmest må tolkes som et forsøg på at genvinde den lokale heterogenitet $i$ en stadig mere globaliseret verden.

For at blive medlem af Cittaslowbevægelsen skal man som by søge om optagelse, hvorefter hovedkontoret i bevægelsens moderland, Italien, tager stilling til, om man som by kan leve op til de krav, der er nedfældet i det såkaldte Cittaslow International Charter. I chartret er der, ud over nogle generelle reglementer, listet 52 kriterier, som man som Cittaslow skal stræbe efter at leve op til. Tilslutter man sig Cittaslowbevægelsen, skal man således arbejde målrettet på at opfylde de 52 kriterier, der anskueliggjort i en komprimeret form især har fokus på at skabe et særligt kvalitativt, unikt og lokalt forankret byrum med rod i byens specifikke historie og kulturelle islæt. Denne strategi skal gå hånd i hånd med æstetiske og bæredygtige tiltag, hvor der ifølge chartret eksempelvis skal arbejdes målrettet på at regulere skiltning og reklame i det offentlige rum, minimere trafikken i byen, fremme etableringen af grønne arealer og revitalisere forsømte byområder. Desuden skal man fra kommunalt hold sikre, at byens ældste bygninger og den oprindelige bystruktur bevares. Medlemskabet af bevægelsen kræver, at man hvert år betaler kontingent til hovedkontoret i Italien i byen Orvieto. "Misligholder" man sine kontingentforpligtelser i mere end to år, eller agerer man i uoverensstemmelse med bevægelsens værdier og principper, kan man blive ekskluderet. Ønsker man som by ikke længere at være medlem, kan man til enhver tid selv melde sig ud på baggrund af en skriftlig begrundelse. Uanset om man bliver ekskluderet eller selv ønsker at forlade bevægelsen, kan man ikke blive certificeret som Cittaslow igen. ${ }^{\mathrm{I}}$ En Cittaslow må som nævnt maks. have et indbyggertal på 50.0oo. Selve Svendborg by huser godt 27.000 indbyggere, mens hele kommunen med den nye kommunale struktur nu samlet set huser 59.000 indbyggere. Svendborg er derfor blevet optaget på baggrund af indbyggertallet i kommunen for kommunalreformen.

I Krav og kriterier er beskrevet i det såkaldte Cittaslow International Charter udarbejdet i Orvieto, Italien I999. Chartret er rekvireret via Svendborg Kommune. Ligeledes er en dansk oversættelse af de 52 specifikke kriterier for medlemskabet af Cittaslowbevægelsen rekvireret via Svendborg Kommune. Kriterierne er delt ind i seks hovedpunkter med følgende overskrifter: I: Miljø, 2: Infrastruktur og byplanlægning, 3: Bykvalitet og teknologiske faciliteter, 4 : Lokale produkter, 5: Gæstfrihed, 6: Information og engagement for Cittaslow. 


\section{Provinsbyen på landkortet}

Et interessant perspektiv ved Cittaslowbevægelsen er, at den har provinsbyen som objekt, hvilket netop er et udtryk for, hvordan de mindre byer stadig mere intensivt forsøger at skabe opmærksomhed omkring sig selv. I kølvandet på kommunalreformen i 2007 har mange danske kommuner for alvor udbygget deres kommunikationsstrategier, og jagten er gået ind på synliggørelsen af en særlig stedsidentitet og stedskvalitet. Dette er ikke mindst affødt af, at det globale informations- og videnssamfund har betydet, at byen i dag må tænke i nye baner som grobund for vækst. Mange traditionelle industrivirksomheder er lukket rundt omkring i de danske provinsbyer, og der satses nu på nye og mere kreative industrier samt på kultur og turisme. Den før så håndgribelige forståelse af, hvad der holdt byens maskineri i gang, og hvad der var dens specifikke erhvervsmæssige profil, er i dag blevet afløst af noget meget mere diffust og uhåndgribeligt. Byen må derfor i stigende grad skabe opmærksomhed omkring sig selv gennem markedsføring og branding, hvilket betyder, at vi på mange måder i dag må betragte byen som en vare, der organiseres som en salgbar enhed (Pedersen). Citybrandingens kulturelle logik handler således i høj grad om at udstyre byen med nye, symbolske merbetydninger som erstatning for den særlige identitet, der er gået tabt i takt med lukningen af det traditionelle industrisamfund. Denne præmis medfører, at citybranding som begreb ligeledes må forstås som et mentalt fokusskifte fra byen som en industriel enhed til en forståelse af byen, der baserer sig på kreativitet, viden og kultur. Der er i mange byer opstået nye alliancer mellem kulturelle institutioner og erhvervslivet som base for fremtidens urbane udvikling, og begrebsliggjort taler man derfor om, at der, med den oplevelsesøkonomiske tilgang til byen, er opstået nye hybride økonomier og nye hybride rum (Kiib og Andersen).

Behovet for at brande sig selv som by og udvise en særlig stedskvalitet hænger igen nøje sammen med, at individet er blevet mobilt som aldrig før og kulturelt frisat. Til forskel fra tidligere, hvor individet i langt højere grad levede sit liv i den egn, hvor det var født og vokset op, så vælger vi i dag selv, hvor og hvordan vi vil leve vores liv. Den engelske sociolog Mike Savage taler om, at vi i dag bosætter os ud fra en selvorienteret strategi, der er kendetegnet ved, at vi aktivt vælger vores lokale tilhørsforhold ud fra en forståelse af, hvor vi føler og fornemmer, der er overensstemmelse mellem vores habitus og det felt, der omgiver os. ${ }^{2}$ Vi føler os således ikke nødvendigvis hjemme i lokaliteter, hvor vi er født og vokset op, men derimod hjemme i lokaliteter, som vi synes stemmer overens med den livshistorie, vi løbende former og konstruerer. ${ }^{3}$ Dette synspunkt får følgeskab af Richard Florida, der i sin seneste bog Den kreative klasses flugt pointerer, at mange amerikanske undersøgelser ligeledes viser, at stedets betydning - folks forestilling om en given lokalitet - har fået afgørende indflydelse på, om man overhovedet overvejer at flytte til et område. Mange mennesker vælger således først at bosætte sig et sted, hvorefter de begynder at søge job (48). 
Savages og Floridas pointering af, hvordan vi i dag vælger vores lokale tilhørsforhold, understreger opfattelsen af byen som en vare - et forbrugsvalg - som individet aktivt vælger til eller fra. Her bliver den symbolske merværdi, der knytter sig til byens brand, en vigtig forudsætning for, at den kan positionere sig i forhold til andre byer og gøre sig gældende i kampen om at tiltrække den rette cocktail af individer og virksomheder, der kan bidrage til byens vækst, velfærdsgrundlag og fremtidige udvikling. Men samtidig er det således også tydeligt, at det globale samfund langtfra har elimineret stedets betydning, når vi anskuer det i en identitetsmæssig og sociologisk optik, hvilket i høj grad underminerer forestillingen om det senmoderne samfund som et udelukkende mobilt og friktionsløst samfund, der har gjort individet rodløst og tilknytningen til stedet flygtig. Savages undersøgelser viser med al tydelighed, at vi aktivt "sætter rødder", som han formulerer det, og konstruerer vores identitet og selvforståelse i samhørighed med den lokalitet, der evner at tilbyde nogle fysiske og symbolske rammer, som stemmer overens med vores individuelle habitus.

\section{Globaliseringen på makroniveau}

Bevæger vi os imidlertid op på makroniveau og anskuer verden fra denne position, så tegner der sig et ganske andet billede af byens, stedets og lokalitetens betydning. Senmoderne sociologiske globaliseringsteorier hviler i høj grad på en teoretisk argumentation for og belysning af, hvordan det fysisk forankrede sted på det økonomiske, strukturelle og kulturelle plan på mange måder har mistet sin betydning som den centrale aktør, når der handles, investeres, udveksles viden, skabes kulturelle trends og tendenser osv. Denne holdning er blandt andre Ulrich Beck eksponent for med sin pointering af det deterritoriale samfund som værende et særligt karakteristisk træk ved globaliseringen. Således påpeger han, at globaliseringen har ophævet territorialiteten som ordningsprincip for vores forståelse og håndtering af samfundet og verdens problemer (86-87). Eksempelvis kan potentielt set alle steder danne rammen om kapitalinvesteringer, og ud af globaliseringen er derfor vokset "det afstandsløse rum", som medfører, at nationalstatens grænser for økonomisk og global aktivitet er blevet sprængt (87).

Anthony Giddens favner på mange måder Becks pointering af deterritorialiseringen med sin vægtning af begrebet udlejring (Giddens, Modernitetens konsekvenser), der netop henviser til den kendsgerning, at megen økonomisk aktivitet, kommunikationsstrømme og sociale relationer i den moderne, globale verden er blevet løftet ud af deres fysisk forankrede sammenhænge og foregår på tværs af tid og

\footnotetext{
2 Savage formulerer dette på følgende måde: "People are 3 Savage formulerer dette på følgende måde: "Belonging comfortable when there is a correspondance between habitus and field" (9). is defined not as an attribute of being born and bred
in a place, but when a chosen place of residence is
congruent with one's life story" (54).
} 
rum. I tråd hermed taler Manuel Castells om det globale netværkssamfund, ligesom Stuart Hall opererer med begrebet komprimeringen af tid og rum som et billede på, hvordan globaliseringen på mange måder har trukket verden sammen ikke mindst på det kulturelle plan. En pointe der får følgeskab af den hollandske arkitekt og byplanlægger Bercei Florian, der påpeger, at sat på spidsen er verden langt hen ad vejen blevet monokulturel, idet én smag, ét sprog og én kultur dominerer verden i dag. Den verdensberømte hollandske arkitekt Rem Koolhaas har ligeledes belyst denne tendens med sine beskrivelser af den generiske by, som i udgangspunktet refererer til den kendsgerning, at byer verden over bliver mere og mere ens som følge af globaliseringens monokultur, amerikaniseringen af det urbane rum og kapitalismens globale kulturindustri.

\section{Fokus på det territoriale rum}

Ovenstående vinkling af globaliseringen viser et tydeligt og paradoksalt træk ved det globale samfunds karakter. På den ene side har stedet mistet betydning, det er blevet deterritorialt og udlejret og udvikler sig i en markant monokulturel retning. På den anden side er det territoriale rum - stedet - simultant hermed kommet stadig mere i fokus, når vi anskuer det på det mentale, identitetsmæssige og sociologiske plan. Byen har altså langtfra udspillet sin rolle som sted, og den er i et citybrandingperspektiv i høj grad blevet et valg - et strategisk livsstilsvalg, et individuelt forbrugsvalg og en del af vores personlige brand. Den enkelte by må derfor mere end nogensinde skabe sig selv som sted for at gøre sig attraktiv og plante sig i individets bevidsthed. I forhold til denne dikotomi mellem det deterritoriale og det territoriale er Cittaslowbevægelsen yderst interessant, fordi den først og fremmest forsøger at generobre det territoriale rum ved at sætte fokus på byen som en størrelse, hvori vi både er fysisk, kropsligt og socialt forankrede. Samtidig sætter den fokus på territorialiteten ved at vriste sig fri af den globale monokultur med ønsket om at brande sig på provinsbyens evner til at fremvise nogle unikke lokale, kulturelle og historiske karakteristika. I et globaliseringsperspektiv må bevægelsen derfor forstås som en moddiskurs, der udtrykker markante behov for at genskabe unikke former for glokaliseringer og ønsker om at synliggøre den lokale heterogenitet.

Flere byplansforskere har påpeget det paradoksale i, at Cittaslowbevægelsen kun vil optage byer med et indbyggertal på maks. 50.0oo, idet det netop er i de allerstørste byer, at vi tydeligst ser resultaterne af den stigende amerikanisering og monokulturelle udvikling. Ideen om Cittaslowbyens maksimale indbyggertal har derfor ligeledes været kritiseret for at hvile på et middelalderligt mytisk og utopisk byideal, der bygger på en anakronistisk forestilling om en tilbagevenden til et gammeldags landsbyfællesskab, hvor man barrikaderer sig mod det fremmede for at beskytte den lokale identitet og kultur. Præsidenten for Cittaslowbevægelsen har i denne forbindelse taget til genmæle ved at hævde, at bevægelsen ikke er imod for- 
andringer, men imod den forkerte måde, disse forandringer sker på, hvor man lukker ned for byens kultur og historie (Craig og Parkins 79). Følger man denne logik er Cittaslowbevægelsen dermed ikke et udtryk for en osteklokkementalitet med ønsket om en statisk og protektionistisk bykulturel strategi, men i langt højere grad et udtryk for, at provinsbyen påberåber sig retten til at være sig selv, at vriste sig fri af den standardisering, der kendetegner udviklingen af mange byer i dag, for at udvikle sig på en måde, der sikrer en fortsat kulturel og lokal pluralitet.

Følger man op på kritikken af Cittaslowbevægelsens ekskludering af de store metropoler, så må forklaringen herpå uden tvivl finde sin begrundelse i, at bevægelsen er "provinsbyens opfindelse" (Cittaslowbevægelsen opstod, som nævnt i den italienske provinsby Greve). Cittaslowbevægelsen er således båret frem af et ønske om at profilere de mindre byer og gøre dem til genstand for et særligt brand, som den globale storby ikke blot kan overtage og fortolke i sit eget udtryk. I en overordnet dikotomi mellem land og by må man derfor forstå profileringen af sig selv som Cittaslow som et ønske om at synliggøre for omverdenen, at man er et godt og nødvendigt alternativ til den globale metropol. Hvor storbyen i en negativ kontekst konnoterer det globale, generiske og monokulturelle, det overfladiske, det stressende og fremmedgørende, så forsøger Cittaslowbyen at favne den særlige livskvalitet og stedsidentitet, som i stigende grad udviskes i de store metropoler: Den unikke lokale kultur, natur og historie, fordybelsen, freden, eftertænksomheden og nærværet mennesker imellem. I denne forbindelse er en interessant dimension ved Cittaslowbevægelsen, at den også brander sig på vigtigheden af at genskabe mellemmenneskelige relationer, hvilket blandt andet kommer til udtryk ved, at Cittaslowbyen ligeledes skal søge at fremme nærdemokrati, borgerinddragelse og offentlige Cittaslowaktiviteter. ${ }^{4}$ Cittaslowbyens sociale ambitioner kan derfor forstås som et interessant opgør med den markante tendens til, at vi rent bosætningsmæssigt grupperer os i homogene livsstilsorienterede enklaver, som Savage netop belyser. En pointe som den hollandske arkitekt og byplanlægger Arnold Reijndorp ligeledes påpeger ved at hævde, at der i det urbane rum er opstået en ny kulturel geografi, hvor vi næsten udelukkende færdes blandt dem, der ligner os selv. Denne tendens har betydet, at selv storbyen er blevet segregeret og har mistet sin tidligere charmerende mangfoldighed, hvor drankeren, forfatteren og arbejderen på trods af forskelligheder boede dør om dør. Forfatteren Søren Ulrik Thomsen har blandt andet med en knivskarp sproglig provokation udtrykt denne tendens ved i et essay at kalde København for et "Parcelhuskvarter på højkant".

I forlængelse af ovenstående karakteriserer den engelske sociolog Sarah Pink netop Cittaslowbevægelsen som udtryk for en ny bykulturel diskurs, der sætter socialiteten i fokus. Hun eksemplificerer i denne forbindelse, hvordan man i den engelske Cittaslowby Ludlow har iværksat projekter med det formål at knytte ind-

4 Disse "krav" optræder som elementer blandt de 52 kriterier for medlemskab i Cittaslow. 
byggerne til byen på det sociale, sanselige og følelsesmæssige plan. Blandt andet har man i Ludlow arrangeret offentlige "brunch events" under navnet "Food Circles", hvor byens borgere samles omkring hinandens mad, ligesom man har iværksat projektet "The Ludlow Skill Building", som forsøger at fremme etableringen af små lokale handelsdrivende med henblik på at skabe et særligt lokalt forankret handelsmiljø. Bæredygtig byudvikling fortolket med Cittaslowbyen som objekt forstår Sarah Pink således i høj grad som en udvikling, der sigter mod at styrke indbyggernes mentale og sanselige bånd til provinsbyen som fundament for dens fortsatte eksistens, attraktivitet og fremtidige muligheder for at skabe vækst. Cittaslowbevægelsen er dermed også et udtryk for en bykulturel strategi, der forsøger at balancere det urbane rum mellem den moderne globale, udlejrede verden og den mere traditionelle, fysisk forankrede territoriale landsbymentalitet.

\section{En transformationsøkonomisk strategi}

Lad os i det følgende vende blikket mod, hvordan Cittaslowbevægelsen med langsomheden indbygget i sin brandingstrategi ligeledes er med til at udfordre vores traditionelle forståelser af den oplevelsesøkonomiske by. Bevægelsen brander sig nemlig ligeledes på, hvor vigtigt det er at sætte farten ned, hvilket kommer til udtryk i et andet oxymoron, som er Cittaslowbyens motto, "at man skal skynde sig langsomt”. Cittaslowbyen ønsker altså at markedsføre sig i forhold til tilstedeværelsen og dyrkelsen af en særlig livskvalitet som det parameter, der adskiller den nævneværdigt fra storbyen og andre byer generelt, hvilket også afspejles i følgende citat hentet fra slowfilosofien:

"At leve i en Cittaslow betyder, at man søger at imødekomme og prioritere kravet om 'det gode liv' [...] At leve i en Cittaslow betyder i korthed at give sig tid til at skabe livskvalitet $i$ alle livets forhold, sætte farten ned og koncentrere sig om byens og verdens smag, farve og duft." (Manifest for Slowfilosofien)

Langsomhed og sanselighed spiller her sammen som to uadskillelige størrelser, idet vi ikke kan sanse byen og livet, som citatet byder, hvis ikke vi samtidig investerer i viljen til at sætte farten ned og spænde ben for det hastighedsræs, der præger vores hverdag i dag. Langsomheden som den kommer til udtryk i Cittaslowbevægelsen er således en tydelig moddiskurs til den oplevelsesøkonomiske orkestrering af byen, idet Cittaslowbyen brander sig selv på et immaterielt plan, hvor parametre som livskvalitet, sanselighed, medmenneskelighed, fordybelse, nærvær og omtanke indgår som vigtige salgsetiketter. At brande sig som Cittaslow kan derfor samtidig forstås som et udtalt ønske om at vende ryggen til det kapitaliserede forbrugssamfund for som modbrand at signalere, at den materielle velstand har nået sit mæthedspunkt, og at vi bør gå på jagt efter noget mere eksistentielt mellemmenneskeligt i forsøget på at finde meningen med livet. Ønsket om at være Cittaslow må således snarere betragtes som en transformationsøkonomisk strate- 
gi frem for en oplevelsesorienteret strategi, idet oplevelsen på det transformationsøkonomiske plan netop ikke skal forstås som noget, der relaterer sig til "underholdning" i bred forstand, men som en strategi, der bevæger sig på det mentale og intellektuelle plan ved at signalere dens evne til at transformere det enkelte individ (Madsen). Denne transformationsøkonomiske strategi spores også i reklamens markedsføringsstrategier, der i dag har gennemgået et diskursskifte fra det rationelle og informative til fordel for det mere emotionelle, der har fokus på, hvad den enkelte vare kan gøre for modtagerens personlighed (Jantzen og Østergaard IO2). Konkretiseret igennem Cittaslowbyen, så ser vi netop, hvordan den i langt højere grad markedsfører sig på, hvordan vi kan ændre os som individer ved at bekende os til det langsomme, fordybende og sansende, end den informerer om, hvad den enkelte by i virkeligheden har at byde på. Med Svendborg som objekt kan man opfatte dette som et skifte fra en informationel til en transformationel advertisering af byen (Jantzen og Østergaard IO2).

\section{Opgør med tidstyranniet}

Den "langsomme" diskurs, som præger både Slow Food- og Cittaslowbevægelsen, vinder i stigende grad indpas i vores kultur på mange planer. Dette kommer blandt andet til udtryk igennem den såkaldte slow living-bølge, som begrebsligt dækker over en række bevægelser, der alle hylder langsomheden som en central værdi (Craig og Parkins). Den stigende insisteren på at leve langsommere ses blandt andet i form af den øgede popularitet omkring wellness, yoga og meditation samt i renæssancen inden for mere tidskrævende kreative hverdagspraksisser såsom strikning, bagning og havearbejde for at nævne nogle helt banale eksempler. I bekendelsen til langsomheden ligger derfor også en kamp for at genvinde tiden i bevidstheden om, at vi er ved at miste den, hvilket har betydet, at refleksioner over og en stillingtagen til, hvordan den kan generobres i hverdagen, i stigende grad trænger sig på. Slow living-bølgen må altså i høj grad forstås som et opgør med det tidstyranni, der præger det moderne menneskes hverdag i dag, hvilket er årsagen til, at det netop er hverdagen - og ikke eksempelvis ferien eller fritiden - som er kommet i søgelyset som genstandsfeltet for en anderledes livsførelse.

Når man som Cittaslow brander sig på langsomhed, må man derfor forstå dette som en bykulturel strategi, der ligeledes forsøger at udfordre og forholde sig kritisk til de fortællinger og værdier, der synes at dominere vores hurtige og hastige hverdag i dag. Som Cittaslow ønsker Svendborg således at signalere, at på Sydfyn findes der en særlig eftertænksom by, som giver individet unikke muligheder for at skabe livskvalitet, ro og fordybelse. Ole B. Jensen, som blandt andet forsker i byplanlægning, favner mange af disse pointer, idet han netop ser viljen til at være en langsom by som en moddiskurs til det friktionfrie samfund, der er kendetegnet ved en stadigt stigende søgen efter rationalitet, højere hastigheder, øget mobilitet og aktionsradius. Drømmen om det friktionsfrie samfund har, påpeger Ole $\mathrm{B}$. 
Jensen, indtil for få år siden fungeret som en uangribelig grundantagelse, som det moderne samfund ikke satte spørgsmålstegn ved. Et kulturelt episteme kunne man sige, idet sandheden omkring det gode samfund indtil nu har været forbundet med hurtighed, mobilitet og effektivitet. En næsten hysterisk higen efter uhindret flow, som han meget rammende udtrykker det. Det er netop denne forestillingshorisont, der nu bliver problematiseret med ønsket om at være en langsom by, og vi må derfor for at kunne forstå denne diskurs sætte den ind i en større sociologisk og idéhistorisk sammenhæng, påpeger Ole B. Jensen. Dette gør han blandt andet ved at personificere modernitetens higen efter friktionsfrihed via den verdenskendte franske arkitekt og byplanlægger Le Corbusier, som måske mere end nogen anden udtrykker drømmen om udvikling, mobilitet og hastighed via den "rette linjes logik". Således konkluderer Ole B. Jensen, at: "Le Corbusier er indbegrebet af motorveje, lige linjer og friktionsløshed” (Io).

Med udgangspunkt i Anthony Giddens' ideer om livspolitikkens frembrud (243-248) kan man ydermere opfatte Cittaslowbevægelsen som en ny bykulturel livspolitisk diskurs, der har afløst modernitetens emancipatoriske diskussioner om, hvordan vi kan forbedre vores levestandard til fordel for fornyede refleksioner over og fokuseringer på, hvordan vi gerne vil leve og indrette vores liv. Cittaslowbevægelsens globale udbredelse må derfor forstås som et tydeligt udtryk for, hvordan livspolitikken netop er ved at få et vigtigt greb i vores måde at anskue byen på. Drømmen om friktionsløshed er med andre ord blevet erstattet af en ny og senmoderne drøm, som handler om, hvilke valg vi bør træffe for at fremme vores livskvalitet. I mange danske kommuner kommer denne diskurs også til udtryk inden for plankulturen, hvor plansystemets værktøjer, der traditionelt set har været knyttet til planjuraen, regulerende bestemmelser og fysiske anlæg, i stigende grad får følgeskab af en række nye bløde værdier, som man i dag forsøger at inkorporere i planlægningen af byens udvikling. ${ }^{5}$

Men svaret på den stigende valorisering af langsomheden skal måske mest af alt findes i den kendsgerning, at det moderne samfunds rationalitet på én og samme tid oplever dets egen irrationalitet (Jensen). Dette kommer blandt andet til udtryk igennem en rationel logik, hvor vi hylder teknologien, effektiviteten, hurtigheden, det omstillingsparate system og hastigheden, samtidig med at vi på paradoksal vis oplever en stigende irrationalitet i form af øgede klimaproblemer, stadig flere stresstilfælde, livsstilssygdomme, depressioner, ulykkelige skilsmisser osv. Langsomheden som værdi og diskurs kan således forstås som en ny og bevidst insisteren på at genfortolke det meningsfulde, det rationelle.

\section{Svendborg - provinsbyen med det gode image}

Vender vi afslutningsvis blikket mod Sydfyn, trænger et særdeles vigtigt spørgsmål sig på: Hvorfor har Svendborg egentlig valgt at blive medlem af Cittaslowbevægelsen? Spørgsmålets relevans skal ses i forhold til den kendsgerning, at Svend- 
borg ifølge flere danske forskningspublikationer scorer særdeles højt på listen over danske provinsbyer, som har et særligt godt image og en evne til at tiltrække både kreative individer og kreative arbejdskræfter. ${ }^{6} \mathrm{Et}$ image der vel at mærke ikke bunder $i$, at byen er Cittaslow - for det er der ikke ret mange, som ved. Ifølge ovennævnte forskning skal svaret på Svendborgs tiltrækningskraft derimod findes i byens mentalitetshistorie. Svendborg er en gammel søfartsby, og byens indbyggere har derfor altid været vant til at møde nye mennesker, hvilket har skabt grobunden for den åbne, tolerante og imødekommende atmosfære, der siges at herske i byen $\mathrm{i}$ dag. I et nyere mentalitetshistorisk perspektiv er denne åbenhed og tolerance blevet understøttet af det miljø, der blev skabt i 1960'erne, hvor mange kreative kræfter flyttede til byen fra København og etablerede Den Røde Højskole. Mentalitetshistoriens synergieffekt ses $\mathrm{i}$ dag $\mathrm{i}$ et stort lokalt engagement, et rigt foreningsliv og en mangfoldighed i kulturudbud (Andersen og Lorenzen 72), der igen har medvirket til at skabe et særligt lokalspecifikt og stedskvalitativt udtryk, som manifesterer sig i et spændende forretnings-, café- og gadeliv, som udspiller sig i et historisk rodfæstet og velbevaret fysisk byrum (Sundbo 19-20). Svendborg lever således og tiltrækker kreative individer, besøgende og turister i kraft af sin helt særlige oplevelsesværdi. Så hvorfor overhovedet ændre strategi, kunne man spørge, når nu det går ganske godt?

Svaret på Svendborgs ønske om at blive Cittaslow må ganske givet findes i den kendsgerning, at bevægelsens ambitioner om at udvikle provinsbyen med udgangspunkt i det lokalspecifikke udtryk netop er en strategi, som praktiseres i Svendborg med stor succes. Man kan derfor tolke det således, at Svendborg ønsker at bruge Cittaslowcertificeringen til at blåstemple sine stedskvaliteter med et implicit håb om, at certificeringen også vil bidrage til at synliggøre Svendborg internationalt, idet bevægelsen opererer globalt.

Det altovervejende problem for Svendborg er imidlertid, at den orange snegl med byen på ryggen endnu er et særdeles ukendt logo for de fleste, og som tegn fungerer det derfor ikke løsrevet som en størrelse, der fortæller os en særlig historie om Svendborg. På nuværende tidspunkt fortæller sneglen ingen anden historie om sig selv end den, vi kender: Et lille slimet og langsomt dyr, der barrikaderer sig i sit trygge hus, så snart verden kommer for tæt på! Den almindelige befolknings manglende kendskab til Cittaslowbevægelsen må selvfølgelig antages at hænge sammen med, at bevægelsen endnu ikke har vundet udbredelse i Danmark. Erfaringer fra Italien viser omvendt, at det i høj grad er muligt at brande en by med

5 'Plano9-projektet', som blandt andet er støttet af Miljøministeriet og Realdania, er et eksempel på, hvordan de mere bløde værdier tænkes ind i plankulturen. På Planog`s hjemmeside hedder det blandt andet, at: "Formålet med Planog er at bidrage til kvalificeringen af det fremtidige plangrundlag i landets 98 kommuner. Sigtet er at skabe optimale rammer for udvikling af livskvalitet gennem det bebyggede miljø til gavn for alle borgere i Danmark" (www.planog.dk).

6 Beskrivelser af Svendborgs image optræder i bogen "Den danske kreative klasse" (Andersen, Lorenzen et al.) samt i rapporten "Udvikling i provinsbyer baseret på oplevelsesøkonomi og den kreative klasse” (Sundbo et al.). 
Cittaslowcertificeringen, og at det skaber stor opmærksomhed i medierne, ligesom Cittaslowbyerne i Italien virker som foregangsbyer for andre (Møller 4). Dette faktum hænger uden tvivl sammen med, at de konnotationer, der knytter sig til Cittaslow i Italien, i høj grad er foranlediget af Slow Food-bevægelsen, som netop er en bredt folkeligt forankret og anerkendt bevægelse, der både praktiseres af husmoderen på landet og inden for det finere gastronomiske køkken. De italienske Cittaslowbyer har således i høj grad draget fordel af at co-brande med Slow Foodbevægelsen.

Det, som på nuværende tidspunkt også gør det svært for Svendborg at brande sig som Cittaslow, må samtidig forstås i forhold til bevægelsens kompleksitet. Cittaslow dækker over noget, som på én gang er meget komplekst og uhåndgribeligt! Byens forsøg på at brande sig som Cittaslow er derfor på mange måder et skoleeksempel på, hvor svært det er, som blandt andet Orvar Löfgren påpeger, at transformere en brandinglogik fra traditionelle forbrugsvarer til en langt mere kompleks størrelse, som byen jo er. For hvad er Cittaslow? Er det hele Svendborg by? Hele kommunen eller kun særligt udvalgte skønne naturområder? Måske noget helt tredje? En særlig måde at være på? En særlig måde at leve på? Man kunne føje endnu flere spørgsmål til denne definitionsrække, men den centrale pointe er, at det på mange måder er ganske uhåndgribeligt at forklare med få ord, hvad Cittaslowbevægelsen er og vil. Cittaslow kan måske mest af alt karakteriseres som brandingen af en særlig bykulturel mentalitet, hvilket besværliggør brandingstrategierne, fordi man ikke umiddelbart har et specifikt afgrænset og konkret objekt at koncentrere brandingen omkring. Samtidig er der rent sprogligt et problem i at brande sig som Cittaslow i Danmark, især i forhold til den ældre del af befolkningen, som hverken taler italiensk eller engelsk. Udfordringen for Svendborg må derfor være, ud over at øge kendskabet til Cittaslow, at synliggøre konkrete manifestationer af, hvad brandet er og i forlængelse heraf forsøge at gøre brandet til en størrelse, som bliver folkeligt forankret.

Når Svendborg skal forsøge at tydeliggøre sin særlige livskvalitet og stedsidentitet som Cittaslow, fremhæver byen ofte den madkulturelle forening Kulinarisk Sydfyn, der både er en varm fortaler for Cittaslow og en ivrig performer af Slow Food-bevægelsens gastronomiske principper. Foreningen er altså en af byens vigtige ambassadører for markedsføringen af Cittaslowstrategien. Men sat på spidsen repræsenterer Kulinarisk Sydfyn snarere caffe latte og lækre tapasspecialiteter frem for brun sovs og kartofler. Et skisma der med al tydelighed viser, at der ofte i en citybrandingstrategi ligger en åbenlys udfordring i, hvordan man undgår, at brandet får en særlig segmenteret betydning. Med et udtryk hentet fra Bourdieu er det således relevant for Svendborg at diskutere, hvordan man undgår, at Cittaslow i for høj grad fortolkes i forhold til den legitime smag, som netop ifølge Bourdieu defineres af den kulturelle elite.

En bred folkelig opbakning til Cittaslow synes at være en nødvendighed, hvis brandet for alvor skal brænde igennem som Svendborgs særlige varemærke og ikke 
blot fremstå som en påklistret etiket. Det er derfor særdeles vigtigt, at Svendborg fremover både positionerer sig som Cittaslow udadtil og indadtil. Der er ingen tvivl om, at der ligger et markant arbejde for Svendborg i udadtil at synliggøre, hvad Cittaslow er, hvis byen ønsker at understrege sit image som en særlig kvalitativ og eftertænksom by. Men skal Cittaslow blive en autentisk del af Svendborgs image, må der på den anden side etableres et ejerskab til Cittaslow blandt byens egne indbyggere, der selv aktivt må bidrage til at tolke og skabe brandet, så det bliver en del af Svendborgs naturlige selvforståelse. Et dristigt træk er netop, at Svendborg nu vil til at "skabe sig" - at konstruere sig selv som Cittaslow frem for bare at være det, den er. Dristigheden i Svendborgs Cittaslowstrategi forstærkes ydermere af, at Cittaslowbevægelsen i sig selv er et enormt og omfattende byudviklingskoncept, der stiller nogle meget restriktive krav til byen, hvilket uundgåeligt gør det svært at balancere brandet mellem teori og virkelighed. Pointen er afslutningsvis, at Svendborg skal være påpasselig med ikke at sælge ud af sin autenticitet og sit gode image, og det vil byen unægtelig gøre i det øjeblik, at Cittaslow dels kommer til at fremstå som en modsætning til de planstrategier, der udvikles i kommunen, og dels kommer til at fremstå som et kommercielt brand, der forsøger at sælge livskvalitet på Sydfyn.

\section{LITTERATURHENVISNINGER}

Andersen, Kristina Vaarst, Mark Lorenzen et al. Den danske kreative klasse - Hvor bor den - Hvem bestär den af? Hvad betyder den for det danske samfund? Århus: Forlaget Klim, 2009.

Arkitekturpolitik - Fokus på vardi og livskvalitet. Rekvireret via Svendborg kommune, 2008.

Beck, Ulrich. “Overgangen fra det første til det andet moderne - fem udfordringer.” SLAGMARK 34 (2002).

Bourdieu, Pierre. "Artistic taste and cultural capital." Culture and society. Cambridge: University Press, I990.

Castells, Manuel. Netvoerkssamfundet og dets opståen. København: Hans Reitzels forlag, 2003.

Cittaslow International Charter. Orvieto, Italien, 1999.

Cittaslow - Ansøgning om optagelse I netvarket - den forste Cittaslowby i Danmark. Rekvireret via Svendborg Kommune, 2007.

Cittaslow-stafetten: Handlingsplan for Cittaslow i Svendborg. Udarbejdet af Pluss Leadership i samarbejde med Svendborg Kommune, 2008.

Craig, Geoffrey og Wendy Parkins. Slow living. Oxford: International Publisher Ltd., 2006.

Engstrøm, Laura. "Alle vil med på succesens verdenskort.” Berlingske Tidende 20. december 2004.

Florian, Bercei. "The city as a brand - orchestrating a unique experience." City Branding - image building and building images. Rotterdam: Netherlands architecture Institute, 2002.

Florida, Richard. Den kreative klasses flugt. Århus: Forlaget Klim, 2007. 
Giddens, Anthony. Modernitetens konsekvenser. København: Hans Reitzels Forlag, I994.

Giddens, Anthony. Modernitet og selvidentitet. København: Hans Reitzels Forlag, I996.

Hall, Stuart. "The question of cultural identity.” Modernity. An introduction to Modern Societies. Red.

Hall, Held, Hubert og Thompson. Oxford: Blackwell Publishing, (7. udgave), 2005.

Hornskov, Søren Buhl. "Affective Architecture in the Branding Cities.” Fun City. Red. Gitte Marling og Martin Zerlang. København: Arkitektens Forlag, 2007.

Jantzen, Christian og Tove A. Rasmusen, red. Forbrugsituationer. Perspektiver på oplevelsesøkonomi.

Aalborg: Aalborg Universitetsforlag, 2007.

Jantzen, Christian og Per Østergaard. "NYD DET! NYD DET! Den moderne hedonisme og dens mentalitetsforudsætninger.” Oplevelsesøkonomi. Vinkler på Forbrug. Aalborg: Aalborg Universitetsforlag, 2007.

Jantzen, Christian og Mikael Vetner. “Oplevelsens psykologiske struktur.” Oplevelsesøkonomi. Produktion, forbrug, kultur. Frederiksberg: Forlaget Samfundslitteratur, 2008.

Jensen, Ole B. "Brand resistance and counter-branding.” Fun City. Red. Gitte Marling og Martin Zerlang. København: Arkitektens Forlag, 2007.

Jensen, Ole B “Viljen til friktion - skal byer nu til at være langsomme med vilje." Medlemsblad for: Foreningen Dansk Byøkologi 2 (juni 2003).

Johannsen, Hans Henrik Winther og Lars Overgaard Jørgensen. "Cittaslow bevægelsen - gammel vin på nye flasker?” Medlemsblad for: Foreningen Dansk Byøkologi 2 (juni 2003).

Kiib, Hans og Lasse Andersson. “The City's New Hybrid Experience Space.” Fun City. Red. Gitte

Marling og Martin Zerlang. København: Arkitektens Forlag, 2007.

Kloster, Martin. “Citta-hvad??????” Fyens Stiftstidende. 19. april 2009.

Koolhaas, Rem. "Den generiske by." Kritik I70 (2004).

Lash, Scott og Celia Lury. Global Culture Industry. Cambridge: Polity Press Cambridge, 2007.

Lund, Jacob m.fl. Følelsesfabrikken. København: Børsens Forlag, 2007.

Löfgren, Orvar. "First we take Manhatten, then we take Berlin: Branding in the Experience City.” Fun City. Red. Gitte Marling og Martin Zerlang. København: Arkitektens Forlag, 2007.

Madsen, Karen Hvidtfeldt. "Svendborg - garanteret uden oplevelser?" Cittaslow-byudvikling med udsyn og omtanke?” Red. Helle Juul Kristensen, Johs. Nørregaard Frandsen og Jørgen Møller. Odense: Syddansk Universitetsforlag, 20IO. http:/www.byplanlab.dk/plano9/www.plano9.dk/Projekter/ Projekter_om_KPog/Svendborgog.htm.

Manifest for Slowfilosofien, rekvireret via Svendborg Kommune, 2007.

Mommaas, Hans. "City Branding: The necessity of socio-cultural goals." City Branding - image building and building images. Rotterdam: Netherlands Architecture Institute, 2002.

Møller, Jørgen et al. “Cittaslow - et internationalt netværk for byer med et godt liv.” Medlemsblad for: Foreningen Dansk Byøkologi 2 (juni 2003).

Pedersen, Søren Buhl, Christian Tangkjær og Andersen Linde-Laursen. Mellem postkort og politisk strategi-branding af nationer, regioner og byer. København: Copenhagen Business School, 2003.

Pine, B.J. og J.H. Gilmore. Welcome to the experience economy. Boston, Massachusetts: Harvard Business Review, I998.

Pine, B.J. og J.H. Gilmore. Authenticity - What consumers really want. Boston, Massachusetts: Harvard Business School Press, 2007. 
Pink, Sarah. "Sense and sustainability: The case of the Slow City movement." Local Environment I3.2 (2008): 95-106.

Rasmussen, Tove A. "Oplevelsesøkonomien og dens grænser.” Oplevelsesøkonomi-Produktion, forbrug, kultur. Red. Jørgen Ole Bærenholdt og Jon Sundbo. Frederiksberg: Forlaget Samfundslitteratur, 2007.

Reijndorp, Arnold. "New public domains - the city inside out.” Fun City. Red. Gitte Marling og Martin Zerlang. København: Arkitektens Forlag, 2007.

Savage, Mike. Globalization and belonging. London: Sage Publication, 2004.

Speaks, Michael. "Individualization without identity." City Branding - image building and building images. Rotterdam: Netherlands Architecture Institute, 2002.

Strategi Svendborg 08 - Planstrategi og lokal Agenda 2I. Rekvireret via Svendborg kommune, 2008.

Sundbo, Jon et al. Udvikling i provinsbyer baseret på oplevelsesøkonomi og den kreative klasse. Roskilde: Center for oplevelsesforskning, RUC, 2008.

Thomsen, Søren Ulrik. "Essay - Parcelhuskvarter på højkant.” Politiken 2. august 2002.

Weiss, Birthe. "Liv søges.” Weekendavisen I4. december 200 . 